\title{
The Evaluation of Patients with Severe COVID-19 Pneumonia Who are Recieving Favipiravir Treatment
}

\author{
Favipiravir Tedavisi Alan Ciddi COVID-19 Pnömonili Hastaların Değerlendirilmesi
}

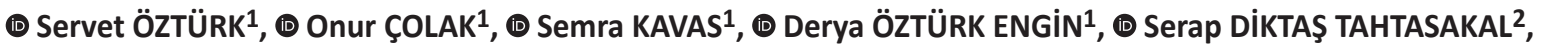 \\ ๑ Dilek ERDOĞAN ARI ${ }^{3}$, ๑ Öznur DEMIROLUK ${ }^{3}$, ๑ Berna ÖZDEMIR ${ }^{1}$, ๑ Büşra Meral ÇETiNKAYA ${ }^{1}$, ๑ Merve KAÇAR EKER ${ }^{1}$, \\ (๑) İrem Asena DOĞAN ${ }^{1}$, ๑ Haluk VAHABOĞLU ${ }^{4}$, ๑ Canan AĞALAR ${ }^{1}$ \\ 1 University of Health Sciences Turkey, Fatih Sultan Mehmet Training and Research Hospital, Clinic of Infectious Diseases and Clinical \\ Microbiology, Istanbul, Turkey \\ 2University of Health Sciences Turkey, Fatih Sultan Mehmet Training and Research Hospital, Clinic of Pulmonary Diseases, Istanbul, Turkey \\ 3 University of Health Sciences Turkey, Fatih Sultan Mehmet Training and Research Hospital, Clinic of Anaesthesiology and Reanimation, Istanbul, \\ Turkey \\ ${ }^{4}$ istanbul Medeniyet University Faculty of Medicine, Department of Infectious Diseases and Clinical Microbiology, Istanbul, Turkey
}

\section{Abstract}

Introduction: There is no known specific treatment for Severe Acute Respiratory Syndrome-Coronavirus-2 (SARS-CoV-2). Our retrospective study evaluates the effectiveness of steroid treatment and the factors affecting treatment in patients with severe Coronavirus disease-2019 (COVID-19) pneumonia that received favipiravir treatment.

Materials and Methods: This study included patients older than 18 years with severe COVID-19 pneumonia who received favipiravir treatment in a training and research hospital between March 1 and May 31, 2020. It retrospectively evaluated respiratory rate $>30 / \mathrm{min}$ and/or severe respiratory distress and oxygen saturation $<90$ and typical thoracic computerized tomography findings: Bilateral lobular, peripheral lesions, and the presence of ground-glass opacities were determined as the criteria for severe pneumonia. For 82 cases of SARS-CoV-2 polymerase chain reaction positive, age, gender, symptoms, comorbidities, steroid use, and mortality rates were examined.

Results: Eighty-two patients with confirmed COVID-19 diagnosed with severe pneumonia were included in the study. Of these cases, $63 \%$ were males. The median patient age was $64 \pm 16.98$ (21-97, minimum-maximum) years. The mortality in women was $23 \%$, and the mortality in men was 30\%. The correlation between gender and mortality was statistically significant $(p=0.04)$. Advanced age, chronic renal failure, and confusion on hospital admission were associated with mortality $(p=0.04, p=0.02, p=0.02$, respectively). Methylprednisolone was given to 12 patients as an additional treatment. The mortality of the patients who received steroid treatment was significantly lower than those who did not ( $p=0.017)$. There was no bacterial infection in these 12 patients, who received steroid treatment and the procalcitonin level was not high.

Conclusion: In confirmed COVID-19 patients without concomitant bacterial infections, steroid treatment can lower mortality and long-term morbidities. Similar to prospective randomized studies, our study showed that steroid use reduces mortality in patients with severe COVID-19 pneumonia.

Keywords: COVID-19, SARS-CoV-2, favipiravir, steroid

\section{$\ddot{0} z$}

Giriş: Şiddetli Akut Solunum Sendromu-Koronavirüs-2 (SARS-CoV-2) enfeksiyonu için henüz spesifik bir tedavi yoktur. Çalışmamız, favipiravir tedavisi alan şiddetli Koronavirüs hastalığı-2019 (COVID-19) pnömonili hastalarda steroid tedavisinin etkinliğini ve tedaviyi etkileyen faktörleri retrospektif olarak değerlendirmeyi amaçlamıştır.

Cite this article as: Öztürk S, Çolak O, Kavas S, Öztürk Engin D, Diktaş Tahtasakal S, Erdoğan Arı D, Demiroluk Ö, Özdemir B, Çetinkaya BM, Kaçar Eker M, Doğan İ, Vahaboğlu H, Ağalar C. The Evaluation of Patients with Severe COVID-19 Pneumonia Who are Recieving Favipiravir Treatment. Mediterr J Infect Microb Antimicrob. 2021;10:22. 
Gereç ve Yöntem: Bir eğitim ve araştırma hastanesinde 1 Mart-31 Mayıs 2020 tarihleri arasında favipiravir tedavisi kullanan, ağır COVID-19 pnömonili, 18 yaş üstü olgular retrospektif olarak irdelendi. Solunum hızı >30/dakika ve/veya şiddetli solunum sıkıntısı ve oksijen satürasyonu $<90$ olması ve tipik torasik bilgisayarlı tomografi bulgusu: Bilateral lobüler, periferik lezyonlar, buzlu cam opasitelerinin varlığı şiddetli pnömoni kriteri olarak belirlendi. Şiddetli Akut Solunum Sendromu-CoV-2 polimeraz zincir reaksiyonu sonucu pozitif 82 olgu yaş, cinsiyet, semptomları, komorbiditeleri, mortalite oranları, favipiravir tedavi yanıt, mortalite oranları irdelendi.

Bulgular: Çalışmaya şiddetli pnömoni teşhisi konulan COVID-19 doğrulanmış 82 hasta dahil edildi. Olguların \%63'ü erkekti. Hastanın ortanca yaşı $64 \pm 16,98$ idi (21-97, minimum-maksimum). Kadınlarda mortalite oranı \%23 iken erkeklerde \%30 idi. Cinsiyet-mortalite ilişkisi istatistiksel olarak anlamlı bulundu $(p=0,04)$. İleri yaş, kronik böbrek yetersizliği ve bilinç bulanıklığı ile hastane başvurusu mortalite ile ilişkili olarak saptandı ( $p=0,04$, $p=0,02, p=0,02$ ). Ek tedavi olarak metilprednizolon 12 hastaya verildi. Steroid tedavisi alan ve almayan hastalar istatistiksel olarak değerlendirildiğinde, steroid tedavisi alanlarda mortalite istatistiksel olarak anlamlı bir şekilde düşük saptandı $(p=0,017)$. Steroid tedavisi alan hastalarda bakteriyel enfeksiyon saptanmadı ve prokalsitonin düzeyleri yüksek değildi.

Sonuç: Konfirme COVID-19 hastalarında steroid kullanımı mortalite ve uzun süreli morbiditeleri azaltabilir. Prospektif randomize çalışmalara benzer şekilde bizim çalışmamız da, steroid kullanımının ağır COVID-19 pnömonili hastalarda mortaliteyi azalttığını göstermiştir.

Anahtar Kelimeler: COVID-19, SARS-CoV-2, favipiravir, steroid

\section{Introduction}

The Coronavirus disease-2019 (COVID-19) pandemic started in December 2019 in Wuhan, China, and rapidly became a global health crisis that is still ongoing ${ }^{[1]}$. No known, specific treatment is available for COVID-19[2-4]. Supportive treatments, such as oxygen inhalation, nutritional support, and fluid replacement, are being performed. Many antivirals have been tried based on experiences from Severe Acute Respiratory SyndromeCoronavirus-1 (SARS-CoV-1) and Middle East Respiratory Syndrome-Coronavirus (MERS-CoV). Phase 2 and Phase 3 trials are ongoing for antivirals, including favipiravir, remdesivir, interferon, ribavirin, hydroxychloroquine, nitazoxanide, ivermectin, and umifenovir ${ }^{[2,3]}$.

Favipiravir, a guanine derivative and ribonucleic acid (RNA) dependent RNA polymerase inhibitor, is a broad-spectrum antiviral. When it was discovered that the agent is a singlestranded RNA virus, the favipiravir phase studies were also started. In a study comparing favipiravir and lopinavir/ ritonavir use in mild/moderate clinically diagnosed patients, the favipiravir group's viral clearance time was shorter, computed tomography (CT) findings' recovery time was faster, and the side effects were fewer ${ }^{[4]}$.

Previous studies have found that patients with severe pneumonia have more proinflammatory cytokine (plasma IL2, IL7, IL10, GSCF, IP10, MCP1, MIP1A, and TNF- $\alpha$ ) levels compared with patients with mild and moderate pneumonia ${ }^{[5,6]}$. The cytokine storm caused by the proinflammatory cytokines that develop in response to viral infection can lead to Acute Respiratory Distress Syndrome (ARDS), organ failure, and inflammatory lung damage resulting in death ${ }^{[7]}$.

Steroid and immunomodulatory treatments were studied due to the lack of an effective antiviral and the evidence indicating an excessive immune response due to the cytokine storm in COVID-19 patients. However, the World Health Organization does not recommend steroid treatment for COVID-19 except in the presence of indications, such as chronic obstructive pulmonary disease (COPD) exacerbations, asthma, ARDS, and septic shock that are nonresponsive to fluid and vasopressor treatment ${ }^{[8]}$.

Our study aims to evaluate retrospectively the effectiveness of the steroid treatment and the factors that affect the treatment in patients with severe COVID-19 pneumonia that received favipiravir treatment and the epidemiological characteristics of these patients.

\section{Materials and Methods}

\section{Patients and Methodology}

One hundred thirty-six patients older than 18 years old, with severe COVID-19 pneumonia, who received favipiravir treatment in a training and research hospital between March 1 and May 31 were retrospectively evaluated. This study excluded 54 of these 136 patients who received favipiravir treatment because they had negative SARS-CoV-2 polymerase chain reaction (PCR) tests. The daily favipiravir dosage in severe pneumonia was $1,600 \mathrm{mg}$ orally twice daily on day 1 , followed by $600 \mathrm{mg}$ orally twice daily on days 2-5. Methylprednisolone $80 \mathrm{mg} /$ day was administered for five days to some patients whose saturation was below 90 despite oxygen treatment with a reservoir mask with $6 \mathrm{~L} / \mathrm{min}$. The patients were diagnosed with severe COVID-19 pneumonia under the following conditions:

- Respiratory rate $>30 /$ min and/or,

- Severe respiratory distress (dyspnea, use of extra respiratory muscles) and,

- Oxygen saturation $<90$ and,

- Typical thoracic CT finding: Bilateral lobular, peripheral lesions, presence of ground-glass opacities.

Age, gender, symptoms, comorbidities, and mortality rates were recorded for 82 cases that were SARS-CoV-2 PCR positive. Severe Acute Respiratory Syndrome-CoV-2 PCR test negativity 
was documented before the patients were discharged. The favipiravir treatment response, mortality, noninvasive, and invasive mechanical ventilation necessities were evaluated. All these patients received supportive oxygen therapy in the clinic. Those who received treatment in the intensive care unit (ICU) were not administered IV plasma, or biologic agents. Scientific research permission was requested from the Ministry of Health, and online permission was obtained on 12.06.2020 with the form name Fatih Sultan Mehmet Training and Research Hospital-2020-06-06T14_57_06. Ethical approval was obtained (25.06.2020/ref no: 62).

\section{Statistical Analyses}

We performed statistical comparisons using the open-source platform R (Vienna, Austria). Variables with non-normal distribution were summarized with medians and interquartile ranges. Depending on whether the distribution was normal, we applied Student's t-test or the Wilcoxon rank-sum test to analyze continuous variables. Categorical variables were compared using the chi-square test or Fisher's exact test, where required. A $p$ value less than 0.05 (typically $\leq 0.05$ ) was considered significant.

\section{Results}

It was the first admission of all patients to our hospital. All of our patients with severe pneumonia were symptomatic at the first admission. None of them were asymptomatic. Only $8 \%$ of the cases were admitted to the hospital with severe pneumonia. The rest of the patients had mild/moderate pneumonia. $68 \%$ $(n=56)$ of these received hydroxychloroquine treatment, 24\% $(n=20)$ received lopinavir/ritonavir treatment. These patients either finished these treatments and then were given favipiravir treatment or switched to favipiravir. There was no difference in mortality between patients who received hydroxychloroquine or lopinavir/ritonavir before favipiravir treatment or did not have a history of antivirals. The criteria for switching from other antiviral agents to favipiravir were clinical worsening and low saturation $(<90 \%)$. The patients who died and who survived were examined in terms of initiation time of favipiravir, no statistically significant difference was found between the two groups in terms of mortality $(p>0.05)$.

Males comprised $63 \%$ of cases. The median patient age was 64 (21-97, minimum-maximum) years. The most frequent symptoms at admittance were cough, shortness of breath, fever, and fatigue (Table 1).

Thirty-three percent of patients did not have comorbidities. The most frequent comorbidities were hypertension $(\mathrm{HT})$, diabetes mellitus (DM), coronary artery disease (CAD) and COPD (Table 2). The mortality in women was $23 \%$, mortality in men was $30 \%$.
The gender-mortality correlation was statistically significant $(p=0.04)$.

The median age of survivors was 63 , while that of the patients who died was 72 . The correlation between being over 70 years old and the mortality rate was statistically significant ( $p=0.004)$. Mortality was significantly higher in patients admitted with chronic renal disease and confusion $(p=0.02, p=0.02)$. Four of five patients $(80 \%)$ who presented with confusion died. Quick sequential organ failure assessment scores were one in all of these five patients. In addition, there were no physical examination findings of bacterial infection, high procalcitonin, and blood culture positivity in patients presenting with confusion, and sepsis was not considered. Four of five patients $(80 \%)$ with chronic kidney failure died.

All 12 patients who received steroid treatment survived, and $33 \%$ of patients who did not receive steroid treatment died (Table 3). When the patients using and not using steroids were

Table 1. Symptoms at admittance

\begin{tabular}{l|l|l}
\hline Symptom & Number & $\%$ \\
\hline Cough & $32 / 82$ & 39 \\
\hline Shortness of breath & $29 / 82$ & 35 \\
\hline Fever & $27 / 82$ & 33 \\
\hline Fatigue & $13 / 82$ & 16 \\
\hline Diarrhea & $8 / 82$ & 9.8 \\
\hline Sore throat & $5 / 82$ & 6.1 \\
\hline Myalgia & $5 / 82$ & 6.1 \\
\hline Headache & $5 / 82$ & 6.1 \\
\hline Confusion & $5 / 82$ & 6.1 \\
\hline Nausea-vomiting & $2 / 82$ & 2.4 \\
\hline Chest pain & $2 / 82$ & 2.4
\end{tabular}

Table 2. Comorbidities

\begin{tabular}{l|l|l}
\hline Comorbidity & $\begin{array}{l}\text { Total } \\
\text { number }\end{array}$ & $\%$ \\
\hline HT & $36 / 82$ & 44 \\
\hline DM & $19 / 82$ & 23 \\
\hline CAD & $8 / 82$ & 9.8 \\
\hline COPD & $7 / 82$ & 8.5 \\
\hline Malignancy & $6 / 82$ & 7.3 \\
\hline Chronic renal disease & $5 / 82$ & 6.1 \\
\hline History of previous cerebrovascular accident & $4 / 82$ & 4.9 \\
\hline Rheumatic diseases & $4 / 82$ & 3.7 \\
\hline Asthma & $3 / 82$ & 3.6 \\
\hline Heart failure & $2 / 82$ & 2.4 \\
\hline Hypothyroidism & $1 / 82$ & 1.2 \\
\hline
\end{tabular}

HT: Hypertension, DM: Diabetes mellitus, CAD: Coronary artery diseases, COPD: Chronic obstructive pulmonary disease 
Table 3. Steroid use/survived

\begin{tabular}{l|l|l|l}
\hline & $\begin{array}{l}\text { Patients on } \\
\text { steroid therapy }\end{array}$ & $\begin{array}{l}\text { Patients not on } \\
\text { steroid therapy }\end{array}$ & p value \\
\hline Number of patients & 12 & 70 & \\
\hline Survived & $12(100 \%)$ & $47(67 \%)$ & 0.017
\end{tabular}

Table 4. Age and comorbidities of patients using and not using steroids

\begin{tabular}{l|l|l|l}
\hline $\begin{array}{l}\text { Patients on steroid } \\
\text { therapy }\end{array}$ & No, N=70 & Yes, N=12 & p value \\
\hline Survived & $47(67 \%)$ & $12(100 \%)$ & 0.017 \\
\hline Age & $64(52,75)$ & $62(47,65)$ & 0.2 \\
\hline Hypertension & $32(45 \%)$ & $4(33 \%)$ & $>0.9$ \\
\hline Diabetes mellitus & $16(23 \%)$ & $2(16 \%)$ & $>0.9$ \\
\hline COPD & $7(10 \%)$ & $0(0 \%)$ & 0.6 \\
\hline Asthma & $1(1.4 \%)$ & $0(0 \%)$ & $>0.9$ \\
\hline Coronary artery disease & $6(8.6 \%)$ & $2(17 \%)$ & 0.3 \\
\hline Hearth failure & $2(2.9 \%)$ & $0(0 \%)$ & $>0.9$ \\
\hline Malignancy & $6(8.6 \%)$ & $0(0 \%)$ & 0.6 \\
\hline $\begin{array}{l}\text { 'n (\%); median (IQR) } \\
\text { 2Fisher's exact test; Wilcoxon rank-sum test } \\
\text { COPD: Chronic obstructive pulmonary disease, IQR: Interquartile range }\end{array}$
\end{tabular}

compared, no statistically significant difference was found between them regarding comorbidity and age (Table 4).

Methylprednisolone was given to 12 patients, $80 \mathrm{mg}$ per day, for five days as an additional treatment. The mortality of the patients who received steroid treatment was significantly lower than those who did not $(p=0.017)$. There was neither bacterial infection, electrolytes or metabolic imbalance in these 12 patients, who received steroid treatment. The presence of bacterial infection was ruled out clinically, with blood cultures and procalcitonin levels.

There was no statistical difference in mortality rate depending on the prescription time of favipiravir treatment after the symptoms started. Twenty-eight critically ill patients were transferred to the ICU. Only five of these patients survived. Patients who received steroid treatment did not need ICU care.

One month survival was 100\% in 59 patients who did not have mortality.

\section{Discussion}

Despite many published articles about COVID-19, the knowledge about the disease is very limited. Even though many factors affecting disease prognoses have been identified, it is difficult to fix the problems in the treatment process because of many unknown factors.

It is known that COVID-19 causes infection in all age groups, yet the severity of cases, the need for ICU, and mortality rate increase with advanced age $\mathrm{e}^{[9-11]}$. Similarly, our study also indicated that the need for ICU and mortality rate increased with advanced age. Since our study focused on patients with severe pneumonia, the median age is higher compared with other studies, as expected ${ }^{[10]}$. Steroid treatment was not given to any patients in the ICU. At the time of the study, steroid therapy was not given because of concerns about steroid complications, and any future articles showing the benefit of steroids were not published.

Published studies indicate that the disease's prevalence is the same in both genders, alongside studies indicating that it is generally seen in males. However, the severity of the cases and the mortality were always higher in male patients ${ }^{[11,12]}$. In our study, the mortality is significantly higher in male cases, consistent with other studies. The reason why the viral infections have a milder course and have fewer fatal outcomes in women can be the sufficiency of the immune response, the difference in the sex hormones, alongside environmental factors like differences in lifestyles, healthy diet, and less alcohol and tobacco consumption ${ }^{[13,14]}$. The high incidence that was observed in the mortality of the male cases in parallel with the general demographic reality ${ }^{[14]}$.

In our study, the most frequent admittance symptoms were cough, shortness of breath, fever, fatigue, and gastrointestinal symptoms in line with existing literature ${ }^{[4,5,10]}$. Even though the frequency of the symptoms was in line with the literature, the number of symptoms was less than in the literature ${ }^{[5,10]}$. Although general symptoms, such as cough and fever, were above 50\% in many articles, the number of symptoms at hospital admissions was relatively low in our study (cough: $39 \%$, shortness of breath: $35 \%$, fever: $33 \%)^{[5,10]}$. This may be the early admittance of the patients to the hospital because of the panic and fear caused by the pandemic.

It was thought that the high mortality rate of the patients who were admitted with confusion was because of late admission to the hospital and the advanced age of the patients.

The most frequent comorbid diseases were $\mathrm{HT}, \mathrm{DM}, \mathrm{COPD}, \mathrm{CAD}$, and malignancies. The comorbidity of other HT was similar to those found in other viral infections ${ }^{[15]}$. The comorbidities of patients in our study were in line with the literature ${ }^{[5,16]}$. In our study, when the relationship between comorbidities and mortality was examined, the mortality was high in patients with chronic renal failure. However, a significant correlation could not be found between other morbidities and mortality. This can be due to the limited number of cases.

The mortality was 28\% for our study. This high mortality is because the study consisted of patients whose oxygen saturation was below 90, with severe pneumonia. In a study emphasizing the efficacy of lopinavir-ritonavir in patients with 
severe COVID-19 pneumonia with oxygen saturation under 94 , the mortality was $19.2 \%$ in the lopinavir group and $25 \%$ in the standard treatment group. Thus, no statistically significant difference was found ${ }^{[17]}$. Different patient control groups could not be formed in Turkey because the antiviral treatments were arranged according to the health authority's suggestions ${ }^{[18]}$.

Corticosteroids have been tried in ICU for COVID-19 patients. The fact that low mortality and shorter hospital stay in critical SARS cases who received steroids led to the trials of steroids in ICU for COVID-19 patients ${ }^{[19]}$. In some other case reports, the advantages and disadvantages have been discussed ${ }^{[20]}$. A study showed that steroid treatment shortened the hospital stay and lowered patients' mortality rate with community-acquired bacterial pneumonia[ ${ }^{[21]}$. Another study indicated that lowmedium dose steroid treatment lowered the mortality in 30 to 60 days in patients with $\mathrm{H}_{1} \mathrm{~N}_{1}$ pneumonia ${ }^{[22]}$. This study showed that 25-150 mg methylprednisolone for an average of seven days in H1N1 influenza pneumonia increased the 30- and 60-day survival. Similarly, a medium dose (80 mg methylprednisolone) was used for five days.

The cytokine storm can be prevented with early steroid treatment. In a multi-center, randomized, controlled trial, steroid use in moderate-severe ARDS patients lowered the mortality and intubation duration ${ }^{[23]}$. In the light of the literature showing the benefits of steroid use, 12 of 82 patients in this study were given steroid treatment ( $1 \mathrm{mg} / \mathrm{kg} /$ day methylprednisolone), and all of them survived. When the patients who received steroid treatment were evaluated with multiple regression analysis, mortality was significantly lower than other factors $(p=0.017)$. In our study, steroid use reduced mortality in severe COVID-19 patients and is consistent with the literature. No infectious complications, like bacterial infections or sepsis, developed in these patients after steroid treatment.

Alongside this positive feedback, other studies showed that steroid use lengthened the virus clearance time in SARS-CoV-1 and MERS-CoV infections ${ }^{[2,25]}$. A study showed that steroid use in early term SARS-CoV-1 related to the RNA clearance ${ }^{[24]}$. However, the validity of this for SARS-CoV-2 is unclear ${ }^{[26]}$. On the contrary, there has been a study showing that low-dose steroids did not lengthen viral clearance ${ }^{[27]}$.

In the early stages, steroid treatment can prevent cytokine storms, and in the chronic stage, it can prevent conditions that can lead to the need for a lung transplant, like pulmonary fibrosis. Thus, it can be an important treatment choice. It was thought that steroid treatment can hypothetically prevent excessive immune response when given to patients who are not in ICU and are not intubated. Because of this, starting steroid treatment in the ICU could be too late for a clinic response. One study found that early short-term corticosteroid therapy reduced mortality and the need for intensive care and mechanical ventilation ${ }^{[28]}$. In the controlled, open-label RECOVERY study, the use of dexamethasone in patients hospitalized with COVID-19, both in patients who needed invasive mechanical ventilation and in patients who needed oxygen but did not receive respiratory support, was found to have lower 28-day mortality ${ }^{[29]}$.

According to the results of a meta-analysis of 21,350 intubated or severe pneumonia COVID-19 patients from 73 studies, steroid use has been shown to reduce mortality and intensive care attendance regardless of dose. At the same time, this study shows that low-dose corticosteroids do not significantly affect SARS-CoV-2 viral transmission time ${ }^{[30]}$.

In our study, the use of steroids was quite limited due to the avoidance of steroid use in general infectious diseases practice, the lack of sufficient data in the first period of the pandemic, and the SARS-CoV experience did not reduce mortality due to steroid use, prolong viral clearance and due to its potential side effects ${ }^{[31]}$. At the same time, articles were published that early intubation can reduce mortality in the first months of the COVID-19 outbreak ${ }^{[32]}$. At the same time, favipiravir use could only be achieved in patients with severe pneumonia with oxygen saturation below 90 in room air. In the current situation, steroid use and intensive noninvasive respiratory support have positively affected intensive care admission and mortality. For these reasons, we think that our mortality rates were very high $(82 \%)$, especially in our ICU, due to reasons such as inability to use antivirals in the early disease period, steroid use avoidance, early intubation, and prolonged intubation.

The kit and device of COVID-19 PCR tests were not provided in our study because they were studied in different laboratories during the pandemic. Due to our study's retrospective design, it was not possible to access some patient data, like laboratory findings, anosmia, and fever data. These can be listed as the limitations of our study.

\section{Conclusion}

This study was conducted retrospectively and that the number of patients who received steroid treatment was low are restricting factors. The mortality rate was low in patients who received steroid treatment than those who did not and no complications were recorded. In confirmed COVID-19 patients if there are no concomitant bacterial infections, steroid treatment can lower mortality and long-term morbidities. Similar to prospective randomized studies, our study showed that steroid use reduces mortality in patients with severe COVID-19 pneumonia.

\section{Acknowledgment}

English redaction of this article was performed by Ece Ağalar. 


\section{Ethics}

Ethics Committee Approval: The study were approved by the Fatih Sultan Mehmet Training and Research Hospital of Local Ethics Committee (date: 25.06.2020/ref no: 62).

Informed Consent: Retrospective study.

Peer-review: Externally and internally peer-reviewed.

\section{Authorship Contributions}

Surgical and Medical Practices: S.Ö., O.Ç., S.K., D.Ö.E., S.D.T., D.E.A., Ö.D., B.Ö., B.M.Ç., M.K.E., I.A.D., H.V., Concept: S.Ö., O.Ç., S.K., D.Ö.E., S.D.T., D.E.A., Ö.D., B.Ö., B.M.Ç., M.K.E., I.A.D., H.V., Design: S.Ö., O.Ç., S.K., D.Ö.E., S.D.T., H.V., C.A., Data Collection or Processing: S.Ö., O.Ç., S.K., D.Ö.E., S.D.T., D.E.A., Ö.D., B.Ö., B.M.Ç., M.K.E., I.A.D., H.V., C.A., Analysis or Interpretation: S.Ö., H.V., C.A., Literature Search: S.Ö., O.Ç., S.K., D.Ö.E., S.D.T., D.E.A., Ö.D., B.Ö., B.M.Ç., M.K.E., I.A.D., H.V., C.A., Writing: S.Ö., H.V., C.A.

Conflict of Interest: No conflict of interest was declared by the authors.

Financial Disclosure: The authors declared that this study received no financial support.

\section{References}

1. Coronaviridae Study Group of the International Committee on Taxonomy of Viruses. The species Severe acute respiratory syndrome-related coronavirus: classifying 2019-nCoV and naming it SARS-CoV-2. Version 2. Nat Microbiol. 2020;5:536-44.

2. Simşek Yavuz S, Ünal S. Antiviral treatment of COVID-19. Turk J Med Sci. 2020;50:611-9.

3. Chen $C$, Zhang $Y$, Huang J, Yin $P$, Cheng $Z$, Wu J, Chen $S$, Zhang $Y$, Chen $B$, LuM, Luo Y, Ju L, Zhang J, Wang X. Favipiravir versus arbidol for COVID-19: a randomized clinical trial. medRxiv; 2020.

4. Cai Q, Yang M, Liu D, Chen J, Shu D, Xia J, Liao X, Gu Y, Cai Q, Yang Y, Shen C, Li X, Peng L, Huang D, Zhang J, Zhang S, Wang F, Liu J, Chen L, Chen S, Wang Z, Zhang Z, Cao R, Zhong W, Liu Y, Liu L. Experimental Treatment with Favipiravir for COVID-19: An Open-Label Control Study. Engineering (Beijing). 2020;6:1192-8.

5. Huang $C$, Wang $Y, L i X$, Ren L, Zhao J, Hu Y, Zhang L, Fan G, Xu J, Gu X, Cheng Z, Yu T, Xia J, Wei Y, Wu W, Xie X, Yin W, Li H, Liu M, Xiao Y, Gao H, Guo L, Xie J, Wang G, Jiang R, Gao Z, Jin Q, Wang J, Cao B. Clinical features of patients infected with 2019 novel coronavirus in Wuhan, China. Lancet. 2020;395:497-506.

6. Prompetchara E, Ketloy C, Palaga T. Immune responses in COVID-19 and potential vaccines: Lessons learned from SARS and MERS epidemic. Asian Pac J Allergy Immunol. 2020;38:1-9.

7. Infectious Diseases Society of America Guidelines on the treatment and management of patients with COVID-19. Last Accessed Date: 25.06.2020. Available from: https://www.idsociety.org/COVID19guidelines

8. World Health Organization (WHO). Last accessed date: 2020 Nov 14. Available from: https://www.who.int/publications/i/item/clinicalmanagement-of-covid-19

9. Wu Z, McGoogan JM. Characteristics of and important lessons from the coronavirus disease 2019 (COVID-19) outbreak in China: summary of a report of 72314 cases from the Chinese Center for Disease Control and Prevention. JAMA. 2020;323:1239-42.
10. Tian S, Hu N, Lou J, Chen K, Kang X, Xiang Z, Chen H, Wang D, Liu N, Liu D, Chen G, Zhang Y, Li D, Li J, Lian H, Niu S, Zhang L, Zhang J. Characteristics of COVID-19 infection in Beijing. J Infect. 2020;80:401-6.

11. Jin JM, Bai P, He W, Wu F, Liu XF, Han DM, Liu S, Yang JK. Gender Differences in Patients With COVID-19: Focus on Severity and Mortality. Front Public Health. 2020;8:152.

12. Wenham C, Smith J, Morgan R, Gender and COVID-19 Working Group. COVID-19: the gendered impacts of the outbreak. Lancet. 2020;395:846-8.

13. Conti P, Younes A. Coronavirus COV-19/SARS-CoV-2 affects women less than men: clinical response to viral infection. J Biol Regul Homeost Agents. 2020;34:339-43.

14. Jin JM, Bai P, He W, Wu F, Liu XF, Han DM, Liu S, Yang JK. Gender Differences in Patients With COVID-19: Focus on Severity and Mortality. Front Public Health. 2020;8:152.

15. Chow EJ, Doyle JD, Uyeki TM. Influenza virus-related critical illness: prevention, diagnosis, treatment. Crit Care. 2019;23:214.

16. Yang J, Zheng Y, Gou X, Pu K, Chen Z, Guo Q, Ji R, Wang H, Wang Y, Zhou Y. Prevalence of comorbidities and its effects in patients infected with SARSCoV-2: a systematic review and meta-analysis. Int J Infect Dis. 2020;94:195.

17. Cao B, Wang $Y$, Wen D, Liu W, Wang J, Fan G, Ruan L, Song B, Cai Y, Wei $M$, Li X, Xia J, Chen N, Xiang J, Yu T, Bai T, Xie X, Zhang L, Li C, Yuan Y, Chen H,

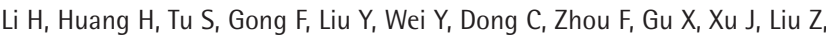
Zhang Y, Li H, Shang L, Wang K, Li K, Zhou X, Dong X, Qu Z, Lu S, Hu X, Ruan S, Luo S, Wu J, Peng L, Cheng F, Pan L, Zou J, Jia C, Wang J, Liu X, Wang S, Wu X, Ge Q, He J, Zhan H, Qiu F, Guo L, Huang C, Jaki T, Hayden FG, Horby PW, Zhang D, Wang C. A Trial of Lopinavir-Ritonavir in Adults Hospitalized with Severe COVID-19. N Engl J Med. 2020;382:1787-99.

18. T.C Sağlık Bakanlığı Bilimsel Danışma Kurulu Çalışması. COVID-19 (SARSCoV-2 enfeksiyonu) erişkin hasta Tedavisi. Erişim adresi: https://covid19. saglik.gov.tr/Eklenti/39061/0/covid-19rehberieriskinhastatedavisipdf.pdf

19. Chen RC, Tang XP, Tan SY, Liang BL, Wan ZY, Fang JQ, Zhong N. Treatment of severe acute respiratory syndrome with glucosteroids: the Guangzhou experience. Chest. 2006;129:1441-52.

20. Gomersall CD. Pro/con clinical debate: steroids are a key component in the treatment of SARS. Pro: Yes, steroids are a key component of the treatment regimen for SARS. Crit Care. 2004;8:105-7.

21. Siemieniuk RA, Meade MO, Alonso-Coello P, Briel M, Evaniew N, Prasad $\mathrm{M}$, Alexander PE, Fei $\mathrm{Y}$, Vandvik PO, Loeb M, Guyatt GH. Corticosteroid therapy for patients hospitalized with community-acquired pneumonia: a systematic review and meta-analysis. Ann Intern Med. 2015;163:519-28.

22. Li $H$, Yang SG, Gu L, Zhang Y, Yan XX, Liang ZA, Zhang $W$, Jia HY, Chen $W$, Liu M, Yu KJ, Xue CX, Hu K, Zou Q, Li D, Cao B, Wang C, National Influenza A(H1N1)pdm09 Clinical Investigation Group of China. Effect of low-tomoderate-dose corticosteroids on mortality of hospitalized adolescents and adults with influenza $A(H 1 N 1) p d m 09$ viral pneumonia. Influenza Other Respir Viruses. 2017;11:345-54.

23. Villar J, Ferrando C, Martínez D, Ambrós A, Muñoz T, Soler JA, Aguilar G, Alba F, González-Higueras $E$, Conesa LA, Martín-Rodríguez $C$, Díaz-Domínguez FJ, Serna-Grande P, Rivas R, Ferreres J, Belda J, Capilla L, Tallet A, Añón $J M$, Fernández RL, González-Martín JM, dexamethasone in ARDS network. Dexamethasone treatment for the acute respiratory distress syndrome: a multicentre, randomised controlled trial. Lancet Respir Med. 2020;8:26776.

24. Lee N, Allen Chan KC, Hui DS, Ng EK, Wu A, Chiu RW, Wong VW, Chan PK, Wong KT, Wong E, Cockram CS, Tam JS, Sung JJ, Lo YM. Effects of early corticosteroid treatment on plasma SARS-associated Coronavirus RNA concentrations in adult patients. J Clin Virol. 2004;31:304-9. 
25. Hui DS. Systemic corticosteroid therapy may delay viral clearance in patients with middle east respiratory syndrome coronavirus infection. Am J Respir Crit Care Med. 2018;197:700-1.

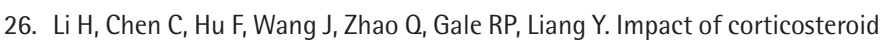
therapy on outcomes of persons with SARS-CoV-2, SARS-CoV, or MERS-CoV infection: a systematic review and meta-analysis. Leukemia. 2020;34:150311.

27. Fang $X$, Mei $Q$, Yang $T$, Li L, Wang $Y$, Tong $F$, Geng $S$, Pan A. Low-dose corticosteroid therapy does not delay viral clearance in patients with COVID-19. J Infect. 2020;81:147-78.

28. Fadel R, Morrison AR, Vahia A, Smith ZR, Chaudhry Z, Bhargava P, Miller J, Kenney RM, Alangaden G, Ramesh MS, Henry Ford COVID-19 Management Task Force. Early short course corticosteroids in hospitalized patients with COVID-19. Clin Infect Dis. 2020;71:2114-20.
29. RECOVERY Collaborative Group, Horby P, Lim WS, Emberson JR, Mafham M, Bell JL, Linsell L, Staplin N, Brightling C, Ustianowski A, Elmahi E, Prudon B, Green C, Felton T, Chadwick D, Rege K, Fegan C, Chappell LC, Faust SN, Jaki T, Jeffery K, Montgomery A, Rowan K, Juszczak E, Baillie JK, Haynes R, Landray MJ. Dexamethasone in hospitalized patients with Covid-19. N Engl J Med. 2021;384:693-704.

30. Cano EJ, Fonseca Fuentes $X$, Corsini Campioli C, O'Horo JC, Abu Saleh O, Odeyemi $Y$, Yadav H, Temesgen Z. Impact of Corticosteroids in Coronavirus Disease 2019 Outcomes: Systematic Review and Meta-analysis. Chest. 2020;S0012-3692:35107-2.

31. Stockman $\sqcup$, Bellamy R, Garner P. SARS: systematic review of treatment effects. PLoS Med. 2006;3:e343.

32. de Simone G, Mancusi C. COVID-19: Timing is Important. Eur J Intern Med. 2020;77:134-5. 